\title{
Testicular structure of three species of neotropical freshwater pimelodids (Pisces, Pimelodidae)
}

\author{
Rodrigo José Guimarães Cruz \& José Enemir dos Santos
}

Programa de Pós-graduação em Zoologia de Vertebrados, Pontifícia Universidade Católica de Minas Gerais. Caixa Postal 2686, 30535-610 Belo Horizonte, Minas Gerais, Brasil. E-mail: enemir@pucminas.br

\begin{abstract}
The testes structure of the following Siluriformes was studied: Pimelodus maculatus (Lacepède, 1803), Iheringichtys Iabrosus (Lütken, 1874) and Conorhynchos conirostris (Valenciennes, 1840). The testes of these species were dissected into cranial and caudal regions. The fringes of mature testes were counted and measured. Student's ttest was used to identify significant differences between fringe lengths of the two regions. To study the whole testes of each species in its resting and mature stage, testes were fixed in Bouin liquid for 6-8 hours and submitted to routine histological techniques. Standard histochemical techniques were used to detect carbohydrates and proteins. The testes of all species were paired and fringed organs. Histologically, cranial fringes of all species were spermatogenic with cells inside cysts at the same phase of development. Caudal fringes of $C$. conirostris were spermatogenic; while P. maculatus and I. labrosus showed caudal fringes only during secretion. Histochemically, neutral glycoproteins, acid glycoconjugates, acid carboxilates, sialomucines, and acid and sulfates glycoconjugates were detected in the caudal fringe secretions of P. maculatus; and neutral glycoproteins in I. labrosus. Significant differences between the fringe lengths of the cranial and caudal regions were found for all the species studied. KEY WORDS. Fringed testes, secretion, seminal vesicle, Siluriformes, testicular gland.
\end{abstract}

RESUMO. Estudou-se a estrutura testicular dos seguintes peixes Siluriformes: Pimelodus maculatus (Lacepède, 1803), Iheringichtys labrosus (Lütken, 1874) e Conorhynchos conirostris (Valenciennes, 1840). Os testículos foram dissecados e divididos anatomicamente em regiões cranial e caudal. As franjas dos testículos em maturação foram contadas e mediu-se o comprimento das mesmas. $O$ teste $t$ de Student foi utilizado para verificar diferenças significativas entre o comprimento das franjas das duas regiões. Para estudo histológico, testículos inteiros de cada espécie, em repouso e em maturação, foram fixados em líquido de Bouin por 6-8 horas e submetidos às técnicas histológicas de rotina. Utilizaram-se técnicas histoquímicas clássicas para detectar carboidratos e proteínas. Os testículos das espécies estudadas são órgãos pares e franjados. Histologicamente, as franjas da região cranial de todas as espécies são espermatogênicas, com células da linhagem em mesma fase de desenvolvimento contidas em cistos. As franjas da região caudal de $C$. conirostris são também espermatogênicas, enquanto $P$. maculatus e $I$. labrosus apresentam franjas caudais exclusivamente secretoras. Histoquímicamente detectou-se na secreção das franjas caudais de P. maculatus glicoproteínas neutras, glicoconjugados ácidos carboxilados, incluindo sialomucinas e glicoconjugados ácidos e sulfatados e em l. labrosus glicoproteínas neutras. Houve diferenças significativas entre o comprimento das franjas das regiões cranial e caudal para todas as espécies estudadas.

PALAVRAS CHAVE. Glândula testicular, secreção, Siluriformes, testículos franjados, vesícula seminal.

The Siluriformes, among the Ostariophysi, are the most diverse fish order: 34 families, 412 genuses and over 2400 species with a wide geographic distribution (Nelson 1994, Helfman et al. 2000). The family Pimelodidae is considered one of the largest and most diverse in fresh waters, presenting over 300 species (Burgess 1989).

The morphology of the reproductive system of male Siluriformes has been shown to be variable: in some families the testes show spermatogenic lineage cells throughout their extension; others present caudal region with seminal vesicles or accessory structures that do not show spermatogenic activity, however, they can store spermatozoa (LEgENDre et al. 1996). Moreover, the caudal region of some Siluriformes' testes is known to present secretory activity without storing spermatozoa (LoIR et al. 1989). Recent studies have revealed that the testes of Iheringichthys labrosus (Lütken, 1874) are fringed, with a peculiar morphofunctional organization containing a spermatogenic cranial region and a secretory caudal region (SANTOS 
et al. 2001). Fringed testes with asynchronous spermatogenic lineage cells have been found in some mature pimelodids (BAzzoli et al. 1997).

It has been suggested that, knowledge of anatomical differences of the reproductive system of teleosts may offer evidence for establishing phylogenetic relationships between similar species (Meinsner et al. 2000). Thus, Mattei (1991) suggested the use of spermatozoa morphology to help studies on taxonomy and phylogeny of fish.

In consideration of the fact that few studies have investigated Siluriformes' testes, especially those of the family Pimelodidae, which is an economically important group, the present study investigated anatomical, biometrical, histological and histochemical differences in the testes of three pimelodids species: with the aim of establishing testicular patterns, that may provide important information to phylogenetic studies.

\section{MATERIAL AND METHODS}

\section{Animals}

Twenty-five males of Pimelodus maculatus (Lacepède, 1803), Iheringichthys labrosus (Lütken, 1874) and Conorhynchos conirostris (Valenciennes, 1840) were used. For each species five males were in the resting stage and 20 in reproductive activity. Fishes were captured, using gill nets with $3-12 \mathrm{~cm}$ mesh size, from November 2001 to October 2002 in the reservoirs of Furnas and Três Marias and also in the São Francisco river, Minas Gerais, Brazil.

\section{Anatomy and biometry}

For each species 15 males in reproductive activity were fixed in 10\% formaldehyde for 24 hours and stored in $70 \%$ alcohol. From each specimen we measured the distance from the rostral edge of the head to the base of the caudal fin: standard length $(\mathrm{mm})$. Testes were removed, measured (longitudinal length) and maintained in 70\% ethanol. Maturing and resting testes were each divided into a cranial and caudal region. The fringes were manually counted and their lengths, in each of two regions of maturing testes, were determined using a caliper.

\section{Statistical analyses}

Significant differences in the length of the fringes between the cranial and caudal regions of the testes were determined using Student's t-test, with a statistical significance level of $\mathrm{p} \leq 0.05$.

\section{Light microscopy}

For each species fragments of cranial and caudal regions of five testes in the resting stage and five in reproductive activity, were fixed in Bouin's fluid for 6-8 hours, embedded in paraffin, sectioned at 3-5 $\mu \mathrm{m}$, and stained with hematoxylin and eosin or Gomori trichrome. To detect carbohydrates and proteins on the testes caudal region, the following histochemical techniques were used: PAS (Periodic Acid-Shiff); Alcian blue pH 0.5; Alcian blue pH 2.5; and ninhydrin-Shiff (Pearse 1985).

\section{RESULTS}

Biometric results of the fishes, and mature testes in this study are showed in table I. A Student's $t$-test showed that the cranial region was significantly longer than the caudal region for all species studied ( $\mathrm{p} \leq 0.05)$. Fringed mature testes and their respective histological section of cranial and caudal regions are presented in figures 1 to 9 .

The testes of all species were paired organs related to the swim bladder cranially and to the kidneys caudally. They showed fringes or lobes that communicated singly, in pairs or in groups of three, through the whole testes (Figs 1, 4 and 7). Mature testes showed prominent fringes in two distinct regions: cranial with approximately $3 / 4$ of the testes total length and caudal with $1 / 4$. Conversely, testes in the resting stage presented smaller fringes in both regions. Each testis had a spermatic duct that joined at their caudal portion, forming the common spermatic duct, which extended to the urogenital papillae.

Cranial fringes of mature testes of $P$. maculatus (Fig. 2) and I. labrosus (Fig. 5) showed seminiferous tubules with an open lumen, filled with spermatozoa, and the wall of the seminiferous tubules was composed of cysts, each of which contained spermatogenic cells in the same stage of development. The caudal fringes showed tubules with prismatic secretory cells and an open lumen filled with secretion (Figs 3 and 6). Cranial fringes of testes in resting stage showed on the wall of the seminiferous tubules cysts only spermatogonia cells and an occluded lumen. However, the tubules on the caudal fringes did not show any secretion, even though they had an open lumen.

In C. conirostris cranial and caudal fringes of mature testes showed exclusively cysts with spermatogenic lineage cells on the wall of the seminiferous tubules, which presented an open lumen with spermatozoa (Figs 8 and 9). Conversely, fringes of testes in resting stage showed only spermatogonia cysts in the wall of the tubules with an occluded lumen.

Histochemical analyses revealed that the secretion inside the tubules on caudal fringes of $P$. maculatus contained neutral glycoproteins, acid glycoconjugates, acid carboxilates, including sialomucines and acid and sulfates glycoconjugates. The secretion on caudal fringes of I. labrosus reacted positively to the histochemical techniques, which indicated the presence of neutral glycoproteins.

\section{DISCUSSION}

In the present study all species of pimelodids showed paired and fringed testes, joined caudally. These anatomic characteristics are common to other Siluriformes, such as: Ictalurus punctatus (Rafinesque, 1818) (SNeED \& Clemens 1963); Heteropneustes fossilis (Bloch, 1794), Clarias batrachus (Linnaeus, 1758) (SIrCar 1970); Pimelodella cristata (Müller \& Troschel, 1848), Rhamdia quelen (Quoy \& Gaimard, 1824), Ageneiosus brevifilis (Linnaeus, 1766) (Lorr et al. 1989); P. maculatus (BAzzoli et al. 1997); Trachelyopterus galeatus (Linnaeus, 1766) (MEIsNer et al. 2000). 

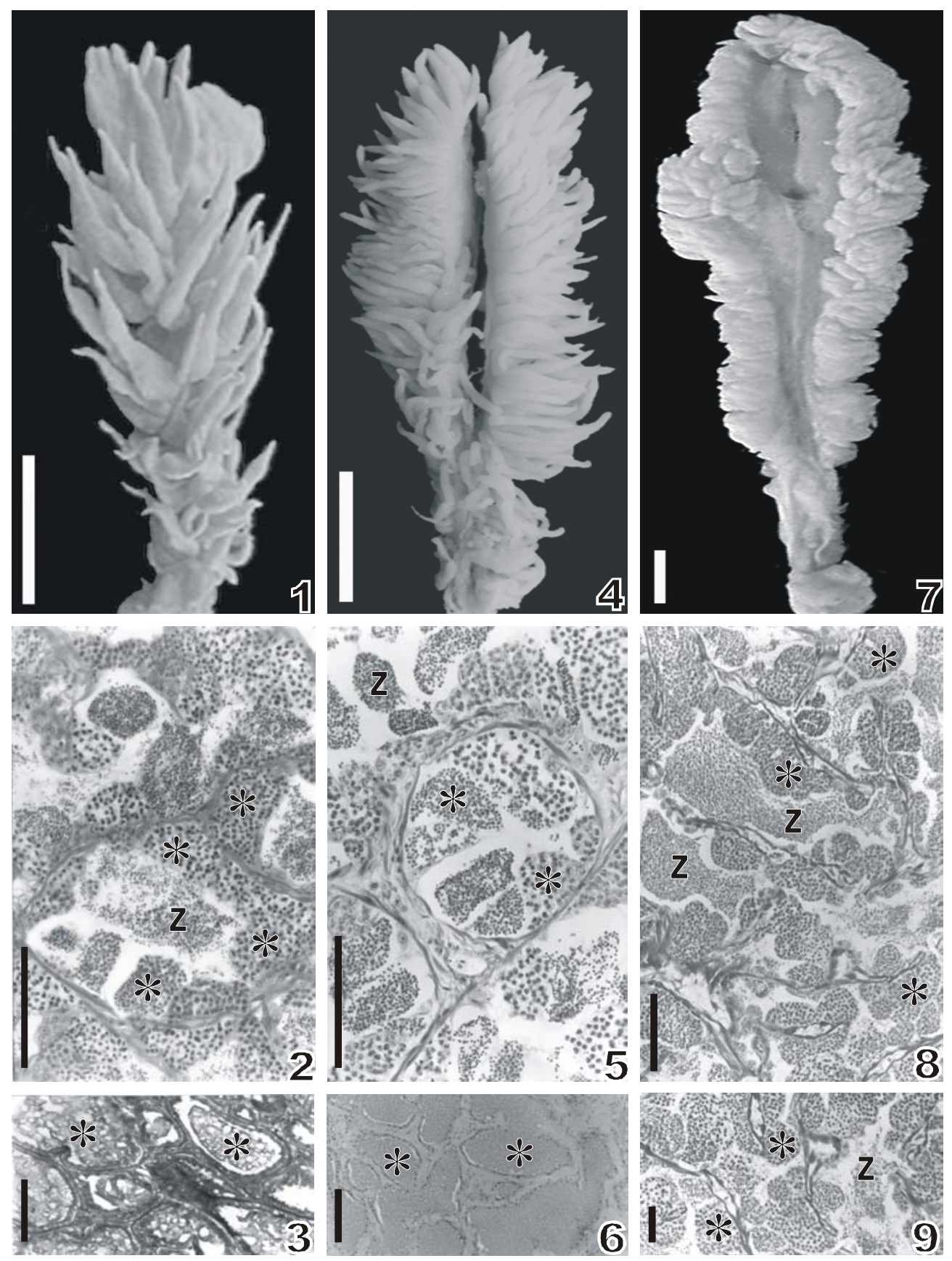

Figures 1-9. Fringed maturing testes and their respective histological section of cranial and caudal regions: hematoxylin and eosin (2, 3, 6, $8,9)$ and Gomori trichrome (5). (1) Fringed maturing testes of $P$. maculatus: (2) spermatogenic activity in seminiferous tubules of cranial region, with cysts of spermatogenic cells in different stages of development $\left({ }^{*}\right)$ and spermatozoa (Z); (3) secretory activity in tubules of caudal region of testes with accumulation of secretion in lumem $\left(^{*}\right) ;(4)$ fringed maturing testes of $I$. labrosus: (5) spermatogenic activity in seminiferous tubules of cranial region, with cysts of spermatogenic cells in different stages of development $\left({ }^{*}\right)$ and spermatozoa (Z); (6) secretory activity in tubules of caudal region of testes with accumulation of secretion in lumem (*); (7) fringed maturing testes of $C$. conirostris: (8-9) spermatogenic activity in seminiferous tubules of cranial and caudal region, respectively, with cysts of spermatogenic cells in different stages of development $\left(^{*}\right)$ and spermatozoa (Z). Scale bars: figures $1,4,7=1 \mathrm{~cm}$; figures $2,3,5,6,8,9=100 \mu \mathrm{m}$. 
Table I. Biometry of fish and mature testes. (SD) Standard deviation.

\begin{tabular}{|c|c|c|c|c|c|c|}
\hline \multirow[t]{2}{*}{ Species } & \multirow{2}{*}{$\begin{array}{l}\text { Specimens' } \\
\text { number }(n)\end{array}$} & $\begin{array}{c}\text { Standard length } \\
(\mathrm{mm})\end{array}$ & $\begin{array}{l}\text { Testes length } \\
(\mathrm{mm})\end{array}$ & Number of fringes & $\begin{array}{l}\text { Cranial fringe lengths } \\
(\mathrm{mm})\end{array}$ & $\begin{array}{c}\text { Caudal fringe lengths } \\
(\mathrm{mm})\end{array}$ \\
\hline & & Mean \pm SD & Mean \pm SD & $\overline{\text { Minimum - Maximum }}$ & Mean \pm SD & Mean \pm SD \\
\hline P. maculatus & 15 & $132.3 \pm 43.4$ & $34.6 \pm 13.9$ & $73-132$ & $6.88 \pm 1.96$ & $2.10 \pm 1.00$ \\
\hline I. labrosus & 15 & $126.0 \pm 9.5$ & $33.7 \pm 4.1$ & $178-204$ & $4.32 \pm 1.02$ & $1.60 \pm 0.45$ \\
\hline C. conirostris & 15 & $465.0 \pm 21.2$ & $108.1 \pm 15.0$ & $1466-1686$ & $4.45 \pm 1.06$ & $2.16 \pm 0.49$ \\
\hline
\end{tabular}

Testes of Pimelodella cristata, Pimelodus ornatus Kner, 1858, Pimelodus blochii Valenciennes, 1840, Pseudopimelodus raninus (Valenciennes, 1840) and R. quelen present variable fringe numbers (Lorr et al. 1989). In the present study three species presented testes with different fringe numbers, the highest being found in C. conirostris (1466 to 1686) and the lowest in $P$. maculatus (73 to 132). In relation to cranial and caudal fringe lengths, there were significant differences among the three species: P. maculatus presented the largest cranial $(6.88 \pm 1.96 \mathrm{~mm})$ and C. conirostris the largest caudal $(2.16 \pm 0.49 \mathrm{~mm})$ fringes.

Testes of $P$. maculatus and I. labrosus showed a spermatogenic cranial region and exclusively secretory caudal region, whereas testes of $C$. conirostris showed spermatogenic activity in both regions. Spermatogenesis occurred synchronously inside cysts throughout the whole seminiferous tubules, as is known for most teleosts (GrIER 1981). In the present study, secretory activity occurred in cells of the seminiferous tubules wall, on caudal fringes without forming conspicuous glands.

Conversely, the Siluriformes H. fossilis, C. batrachus, Trachelyopterus lucenai Bertoletti, da Silva \& Pereira, 1995 and $T$. galeatus have been found to have a secretory caudal region and form seminal vesicles (SIrCAR 1970, MeIsNer et al. 2000). A similar structure was also detected in species of the family Gobiidae (SIrCAR \& HAR 1980, LAHNSTEINER et al. 1992).

Secretory activity in the caudal region of $P$. maculatus and I. labrosus testes was observed only during reproductive period, while in the resting stage no secretion was found inside the seminiferous tubules nor in the testicular ducts. Seasonal variations in weight and secretory activity of these vesicles, in relation to testes cycle have been described for other Siluriformes: Mistus tengara (Hamilton, 1822) (RAstogi 1969), H. fossilis (NAYYAR \& Sundararaj 1970) and C. batrachus (SingH \& Joy 1999). However, WeIsel (1949) did not observe any seasonal changes in length nor in the structure of seminal vesicles epithelial cells of Gillichthys mirabilis Cooper, 1864.

Various substances and functions are related to the secretion produced by the seminal vesicles of teleosts: VAN DER Hurk et al. (1987), LAHNSTEINER et al. (1990), LAHNSTEINER et al. (1992) mentioned that they can store spermatozoa, secrete glycoproteins, steroids and pheromones, increase semen volume and can also influence fertilization, and female attraction. The secretion observed in the present study may have a similar function to that of the seminal vesicles of other teleosts.

The information available in the literature relating to the origin and nomenclature of fish seminal vesicles are speculative. Therefore, Fishelson et al. (1994) demonstrated, through ontogenesis of seminal vesicles of Clarias gariepinus (Burchell, 1822 ) that they are formed in the beginning of spermatogenesis, as a simple protrusion on the wall of the spermatic duct and become complex with age. Sundararaj (1958), Lehri (1967), Rastogi (1969), Nayyar \& Sundararaj (1970), van der HurK et al. (1987), AsAHINa et al. (1989) and LAHNSteiner et al. (1990) affirmed to the presence of the seminal vesicle in some teleosts, notably in catfishes, gobids and blenids. For the species studied in the present work, naming testes caudal fringes, as seminal vesicle is inappropriate, as according to their embryonic and ontogenic development they are not homologous to mammal's seminal vesicle. Therefore the term a testicular gland mentioned by Richtarski \& Patzner (2000) is deemed more suitable.

As herein demonstrated, the testes characteristics of the studied pimelodids presented an unusual pattern in relation to most teleosts. They showed fringes through the whole testes; with significant differences between fringe lengths of cranial and caudal regions; P. maculatus and I. labrosus presented two regions with distinct function: spermatogenic cranial region and secretory caudal region which did not constituted an individual gland, and secretory activity only occurred during the gonadal maturation period. Testes of $C$. conirostris presented cranial and caudal fringes with spermatogenic activity only. These quantitative, biometric and morphological characteristics may provide useful data for phylogenetic analyses of Siluriformes.

\section{ACKNOWLEDGEMENTS}

The authors are grateful to Dr. German A. Bohorquez Mahecha and Dr. Robert J. Young for critical and suggestions; to FIP PUC Minas (2002/07-TLE) for financial support; and to R. Miranda for technical assistance.

\section{REFERENCES}

Asahina, K.; K. Suzuki; T. Hibiya \& B. Tamaoki. 1989. Structure and steroidogenic enzimes of the seminal vesicle of the urohazegoby (Glossogobius olivaceus). General and Comparative Endocrinolology, San Diego, 74: 385-391. 
Bazzoli, N.; L.C.V. Cangussu; E. Rizzo \& G.B. Santos. 1997. Reprodução e desova de mandis Pimelodus maculatus e Iheringichthys labrosus (Pisces, Pimelodidae) nos reservatórios de Furnas, Marimbondo e Itumbiara. Bios, Belo Horizonte, 5 (5): 7-15.

BURGESS, W.E. 1989. An atlas of freshwater and marine catfishes a preliminary survey of the Siluriformes. New Jersey, T.F.H. Publications, I+784p.

Fishelson, L.; J.H.J. van Vuren \& A. Tyran. 1994. Ontogenesis and ultrastructure of seminal vesicles of the catfish, Clarias gariepinus. Journal of Morphology, New York, 219: 59-71.

Grier, H.J. 1981. Cellular organization of the testis and spermatogenesis in fishes. American Zoologist, Thousand Oaks, 21: 345-357.

Helfman, G.S.; B.B. Collette \& D.E. Facey. 2000. Teleosts at Last I: Bonytongues Through Anglerfishes, p. 221-243. In: The Diversity of Fishes. Malden, Blachwell Science Editorial, $\mathrm{XIV}+528 \mathrm{p}$.

Lahnsteiner, F.; U. Richtarski \& R.A. Patzner. 1990. Fucntions of the testicular gland in two blenniid fish, Salaria ( = Blennius) pavo and Lipophrys ( = Blennius) dalmatinus (Blenniidae, Teleostei) as revealed by electron microscopy and enzyme histochemistry. Journal of Fish Biology, London, 37: 85-97.

Lahnsteiner, F.; M. Seiwald; R.A. Patzner \& E.A. Ferrero. 1992. The seminal vesicles of the male grass goby, Zosterisessor ophiocephalus (Teleostei, Gobiidae). Zoomorphology, Berlin, 111: 239-248.

Legendre, M.; O.linhart \& R. Billard. 1996. Spawning and management of gametes, fertilized eggs and embryos in Siluroidei. Aquatic Living Resources, Montrouge, 9: 59-80.

Lehri, G.K. 1967. The annual cycle in the testis of the catfish. Acta Anatomica, Basel, 67: 135-154.

Loir, M.; C. Cauty; P. Planquette \& P.Y. le Bail. 1989. Comparative study of the male reproductive tract in seven families of South-American catfishes. Aquatic Living Resources, Montrouge, 2: 45-56.

Matтer, X. 1991. Spermatozoon ultrastructure and its systematic implications in fishes. Canadian Journal of Zoology, Ottawa, 69: 3038-3055.

Meisner, A.D.; J.R. Burns; S.H. Weitzman \& L.R. Malabarba. 2000. Morphology and histology of the male reproductive system in two species of internally inseminating South American catfishes, Trachelyopterus lucenai and T. galeatus (Teleostei:
Auchenipteridae). Journal of Morphology, New York, 246: 131-141.

NayYar, S.K. \& B.I. Sundararaj. 1970. Seasonal reproductive activity in the testes and seminal vesicles of the catfish, Heteropneustes fossillis (Bloch). Journal of Morphology, New York, 130: 207-226.

NeLson, J.S. 1994. Fishes of the world. New York, John Wiley \& Sons, III+600p.

Pearse, A.G.E. 1985. Histochemistry: theoretical and applied. Edinburgh, Churchill Livingstone, $4^{\text {th }}$ ed., II+1055p.

RASTOGI, R.K. 1969. Seminal vesicles and sperm duct of an Indian catfish, Mystus tengara (Ham.), with particular reference to their seasonal cycle. Acta Anatomica, Basel, 72: 624-639.

Richtarski, U. \& R.A. Patzner. 2000. Comparative morphology of male reproductive systems in Mediterranean blennies (Blenniidae). Journal of Fish Biology, London, 56: 22-36.

Santos, J.E.; N. Bazzoli; E. Rizzo \& G.B. Santos. 2001. Morphofunctional organization of the male reproductive system of the catfish Iheringichthys labrosus (Lütken, 1874) (Siluriformes: Pimelodidae). Tissue and Cell, Essex, 33 (5): 533-540.

SINGH, M.S. \& K.P. Joy. 1999. Annual correlative changes in some biochemical contents of seminal vesicle and testis in catfish Clarias batrachus (L). Zoological Science, London, 16 (2): 345-356.

SIRCAR, A.K. 1970. Morphology of the urinogenital system of some siluroid fishes. Proceedings of the Zoological Society, Calcutta, 23: 93-117,

SirCAR, A.K. \& S.P. HAR. 1980. The seminal vesicles of the bullhead fishes Glossogobius giuris (Hamilton) and Eleotriodes muralis (Valenciennes) (Gobiidae). Proceedings of the Zoological Society, Calcutta, 31: 1-9.

SNeED, K.E. \& H.P. Clemens. 1963. The morphology of the testes and accessory reproductive glands of the catfishes (Ictaluridae). Copeia, Lawrence, 4: 606-611.

SundARARAJ. B.I. 1958. The seminal vesicles and their seasonal changes in the Indian catfish, Heteropneustes. Copeia, Lawrence, 4: 289-297.

van den Hurk, R.; J.W. Resink \& J. Peute. 1987. The seminal vesicle of the African catfish, Clarias gariepinus: histological, histochemical, enzyme-histochemical, ultrastructural. Cell and Tissue Research, New York, 247 (3): 573-582.

Weisel, G.F. 1949. The seminal vesicles and testes of Gillichthys, a marine teleost. Copeia, Lawrence, 30 (2): 101-110.

Received in 15.VII.2003; accepted in 18.V.2004. 